\title{
Isolated Left Ventricular Apical Hypoplasia: A Case Report and Literature Review
}

\author{
Tongning Wang ${ }^{*}$, Hui Chen, Xiaohai Ma and Zhanming Fan
}

Department of Radiology, Capital Medical University Affiliated Anzhen Hospital, Beijing, PR China

"Corresponding author: Tongning Wang, Department of Radiology, Capital Medical University Affiliated Anzhen Hospital, Beijing, PR China, Tel: +8613810023121; Email: 1146696686@qq.com

Received date: August 13, 2016, Accepted date: August 14, 2016, Published date: August 22, 2016

Copyright: (c) 2016 Wang T, et al. This is an open-access article distributed under the terms of the Creative Commons Attribution License, which permits unrestricted use, distribution, and reproduction in any medium, provided the original author and source are credited.

\begin{abstract}
Isolated left ventricular apical hypoplasia (LVAH) is a newly recognized, rare cardiomyopathy which was first described in 2004. Until now, only 20 English-language literatures in relationship with Isolated LVAH were collected from PubMed by the author of this article. We report a case of 50 -year-old man by health-examination without any symptom as this patient was first diagnosed in our hospital. This article includes two parts: case report and literature review.
\end{abstract}

Keywords: Isolated left ventricular apical hypoplasia; Echocardiography; Cardiomegaly

\section{Case Report}

A 50-year-old man was examined by echocardiogram as a bodyhealth examination which showed a ball-like enlarged left ventricle. He had no symptom and no past medical history. Thus he was suggested for cardiovascular magnetic resonance (CMR) after abnormal echocardiography as no reason was available to explain his asymptomatic cardiomegaly. CMR demonstrated a bizarre LV with spherical configuration, truncated apex, interventricular septum bulging to the right (Figure 1A), elongated RV wrapping around the deficient LV apex (Figure 1A), replacement of the LV apex with fatty material (Figure $1 \mathrm{~B}$ and $1 \mathrm{C}$ ).

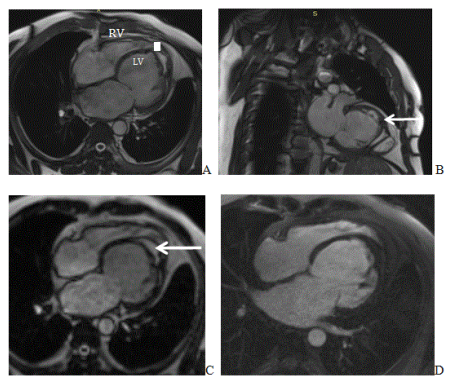

Figure 1: A 50-year-old man with asymptomatic Isolated left ventricular apical hypoplasia. A: A bizarre LV with spherical configuration, truncated apex, interventricular septum bulging to the right; elongated RV wrapping around the deficient LV apex. B: Replacement of the LV apex with fatty material. C: Replacement of the LV apex with fatty material. D: Contrast imaging showed no thrombus and no late enhancement of these areas.

Contrast imaging showed no thrombus and no late enhancement of these areas (Figure 1D) The LV was shortened with apical fatty replacement and the right ventricle wrapped around it. The CMR appearances were rare and not in accordance with dilated cardiomyopathy or any other common cardiomyopathy. The lack of scarring excludes several acquired conditions. Actually, the images are typical for the Isolated LVAH. He was the first patient for diagnosing this rare disease in our hospital. The patient left our hospital since no symptom could be found.

\section{Literature Review}

Isolated left ventricular apical hypoplasia (LVAH) is a newly recognized, rare cardiomyopathy which was first described in 2004 in a case report by Fernandez-Valls et al. [1]. Until now, about 20 Englishlanguage literatures were reported. It was characterized by:

- a truncated and spherical LV configuration with rightward bulging of the interventricular septum,

- deficiency of the myocardium within the LV apex with adipose tissue infiltrating the apex,

- origin of the papillary muscle in the flattened anterior apex and

- elongation of the right ventricle wrapping around the deficient LV apex [2].

\section{Conclusion}

This anomaly may occur as an isolated congenital anomaly or in conjunction with other congenital cardiac abnormalities, such as PDA [3]. The clinical presentation varies from asymptomatic [2-4] to lethal consequence [5]. Therefore, a close follow-up is needed even in asymptomatic patients. A systemic review of the literature was performed to identify all English-language case reports of Isolated LVAH. Eligible studies had to be consistent for patients' radiological findings in exception of their age, gender and so on. In this study 22 patients were reported in these literatures: Age: the minimum is 3month-old [6], the maximum is 66-year-old [7], and the mean age is 29-year-old. Gender: Male: 9 [1,5,7-13]; Female: 11 [1,8-20]. Not reported: 2 [4]. Initial Symptoms: Atypical discomfort in the region of chest: 9 [2,4,8-15,17]; Arrhythmia: 2[9,18]; Murmur: 6 [6,10,12,14]; Dyspnea: 2 [9,13]; Heart failure: 3 [4,18,19]; Not reported: 1 [12]. 
Citation: Wang T, Chen H, Ma X, Fan Z (2016) Isolated Left Ventricular Apical Hypoplasia: A Case Report and Literature Review. J Gen Pract (Los Angel) 4: 267. doi:10.4172/2329-9126.1000267

Page 2 of 2

Prognosis: Asymptomatic: 1 [4]; Atrial Fibrillation: 1 [4]; Medicinecontrolled: 2 [15,19]; Die: 1 [5]; Not reported: 17 [3,8-14]. As to the etiology of Isolated LVAH, it remained unclear. However, one literature reported the mutation of the lamin $\mathrm{A} / \mathrm{C}$ gene was associated with this rare disease [20], which would be beneficial for explore the etiology of this disease.

\section{References}

1. Vanhecke TE, Decker J, Leonowicz N, Chinnaiyan KM (2011) Isolated left ventricular apical hypoplasia. Congenit Heart Dis. 6: 646-649.

2. Haffajee JA, Finley JJ, Brooks EL, Kuvin JT, Patel AR (2011) Echocardiographic characterization of left ventricular apical hypoplasia accompanied by a patent ductus arteriosus. Eur J Echocardiogr 12: E17.

3. Melendez G, Munoz L, Meave A (2010) Isolated left ventricular Apical Hypoplasia. Rev Esp Cardiol 63: 984.

4. Patrianakos AP, Protonotarios N, Zacharaki A, Tsatsopoulou A Parthenakis FI, et al. (2010) Isolated left ventricular apical hypoplasia: a newly recognized unclassified cardiomyopathy. J Am Soc Echocardiogr. 23: e1-e4.

5. Irving CA, Chaudhari MP (2009) Fatal presentation of congenital isolated left ventricular apical hypoplasia. Eur J Cardiothorac Surg 35: 368-369.

6. Marin C, Sanchez ML, Maroto E, Ossaba S, Ruiz Y, et al. (2007) MR imaging of isolated left ventricular apical hypoplasia. Pediatr Radiol 37: 703-705.

7. Braga CG, Silva P, Magalhaes S, Bettencourt N, Themudo R (2014) Isolated left ventricular apical hypoplasia. Eur Heart J 15: 1399.

8. Motwani M, Chb MB, Witte KK, Sven MD (2011) Greenwood, PHD. Isolated left ventricular apical hypoplasia Evaluated by Cardiovascular Magnetic Resonance and Gadolinium Enhancement techniques. J Am Col Cardiol 58: 2355.

9. Moon JI, Jeong YJ, Lee G, Choi JH, Lee JW (2013) Isolated Left Ventricular Apical Hypoplasia with Infundibular Pulmonary and Aortic Stenosis: a Rare Combination. Korean J Radiol 14: 874-877.
10. Sani ZA, Vojdanparast M, Rezaeian N, Seifi A, Tehrani SO, et al. (2016) Left ventricular apical hypoplasia: Case report on cardiomyopathy and a history of sudden cardiac death. ARYA Atheroscler 12: 50-54.

11. Zhao Y, Zhang J, Zhang J (2015) Isolated Left Ventricular Apical Hypoplasia with Right Ventricular Outflow Tract Obstruction: A Rare Combination. Ann Noninvasive Electrocardiol 20: 502-505.

12. Starmer G, Younger JF, Stewart P (2011) Multimodality imaging of isolated left ventricular apical hypoplasia. Eur Heart J 33: 675.

13. Fernandez-Valls M, Srichai MB, Stillman AE, White RD (2004) Isolated left ventricular apical hypoplasia: a new congenital anomaly described with cardiac tomography. Heart 90: 552-555.

14. Hong SA, Kim YM, Lee HJ (2016) Three-Dimensional EndoCardiovascular Volume-Rendered Cine Computed Tomography of Isolated Left Ventricular Apical Hypoplasia: A Case Report and Literature Review. Korean J Radiol 17: 79-82.

15. Ding WY, Meah M, Rao A, Fairbairn T, Hasleton J (2016) Isolated Left Ventricular Hypoplasia in a Postpartum Patient. Can J Cardiol 32: 829.e15-829.e17.

16. Orsborne C, Schmitt M (2014) Isolated left ventricular apical hypoplasia, characterized by cardiac magnetic resonance imaging. Eur Heart J 35: 3303.

17. Tumabiene KD, Magpali AE Jr, Chiong L, Jara RD, Abarquez RF Jr, et al. (2012) A plump and fatty heart: isolated left ventricular apical hypoplasia. Echocardiography 29: E193-E196.

18. Ong CC, Hia CP, Lim TC, Teo LL (2012) Isolated left-ventricular apical hypoplasia presenting as a left-ventricular mass on echocardiography. Pediatr Cardiol 33: 1456-1457.

19. Flett AS, Elliott PM, Moon JC (2008) Images in cardiovascular medicine. Cardiovascular magnetic resonance of isolated left ventricular apical hypoplasia. Circulation 117: e504-e505.

20. Pica S, Ghio S, Raineri C, Scelsi L, Turco A, et al. (2014) Mutation of the lamin A/C gene associated with left ventricular apical hypoplasia: a new phenotype for laminopathies? G Ital Cardiol 15: 717-719. 